\title{
Planos Diretores, Perspectiva Legal e Organização do Território para o Turismo
}

\author{
Master Plans, Legal Perspective and Territory Organization for Tourism
}

\author{
Renata Maria Ribeiro (RIBEIRO, R. M.)*
}

RESUMO - O planejamento do turismo está presente na literatura técnica. Mas nem sempre está relacionado ao Plano Diretor das cidades. Esta realidade infere ao município um crescimento desordenado que afeta o desenvolvimento da atividade. $\mathrm{O}$ Bacharel em Turismo possui a atribuição de iniciar o processo de inclusão do turismo na discussão referente ao planejamento territorial, uma vez que empreendimentos e atrativos turísticos ocupam espaços e induzem a demanda ao destino. Observar o território a partir das legislações existentes pode garantir a inclusão do turismo ao planejamento de produtos turísticos organizados em áreas públicas e privadas da cidade.

Palavras chave: planejamento territorial, turismo, plano diretor.

\begin{abstract}
The tourism planning is present in the technical literature. But not always is related to the Master Plan of the cities. This infers to the municipality disorderly growth that affects the development of activity. The tourism graduated professional has the assignment to initiate the process of inclusion of tourism in a discussion relating to territorial planning, since tourist enterprises and attractions occupy spaces and induce demand to the destination. To note the territory from the existent law can ensure the inclusion of tourism in the planning of tourism products organized in public and private areas in the city.
\end{abstract}

Key words: territorial planning, tourism, master plan.

\footnotetext{
* Formação: Graduação em Turismo (Bacharelado), Mestrado em Geografia e Doutorado em Geografia pela Universidade Federal do Paraná (UFPR). Atualmente é Professora Assistente e Coordenadora Executiva do Campus de Rosana da UNESP. Endereço físico para correspondência: UNESP- Campus Rosana. Av. Barrageiros, 1881 (Bairro Primavera). CEP: 19.274-000 - Rosana - São Paulo (Brasil). Telefone: (18) 3284-9200 - ramal: 9239. Membro do Conselho Científico da Revista Turismo e Sociedade desde o ano de 2008. E-mail: renata@ rosana.unesp.br
} 


\section{INTRODUÇÃO}

O estudo que envolve o tema turismo e território é amplamente difundido por pesquisadores que inter-relacionam a ocupação do espaço às suas várias formas de utilização. Nessa perspectiva, o turismo atua como coadjuvante na composição de infraestruturas específicas. Pode-se observar empreendimentos diversos, assim como a estruturação de recursos naturais e/ou culturais em atrativos turísticos, para somar ao que se pode chamar de produto turístico nas cidades e suas adjacências.

A questão é: de que modo esse espaço é organizado? Como a ocupação é planejada aos empreendimentos que darão suporte ao turismo? Em que medida a espontaneidade de expansão ao território torna-se benéfica ao longo do tempo, considerando que a cidade é como um organismo vivo em constante transformação?

Longe da crítica, essa discussão pretende opinar sobre a atuação do Bacharel em Turismo em não somente discutir o planejamento do turismo (inventário, diagnóstico e prognóstico) que culminam no Plano de Desenvolvimento do Turismo, mas que a esse profissional seja imprescindível a atuação no estudo e discussão quanto a ocupação do espaço a partir das territorialidades implícitas à sociedade.

Nessa perspectiva, a linha mestre ao desenvolvimento da cidade é o Plano Diretor Municipal. Documento formalizado com o objetivo de traçar o planejamento municipal em suas diversas vertentes, seja política, saúde, educação, lazer, mobilidade, turismo, entre outros, com o propósito de conduzir a máquina pública de modo ordenado.

\section{PLANO DIRETOR MUNICIPAL E TURISMO}

Na disciplina de Turismo no Espaço Urbano, a presente autora questiona aos alunos quanto às prerrogativas legais de subsídio ao planejamento do turismo que poderiam apoiar justificativas e ações afirmativas a projetos turísticos apresentados por Bacharéis em Turismo. Pede-se que façam um exercício a partir da leitura da Constituição Brasileira (1988) nos Artigos 182 e 183 que tratam da Política Urbana que foram regulamentados pela Lei 10.257/2001 denominada Estatuto da Cidade que define 
diretrizes ao Plano Diretor.

Eis que no Art. 41 tem-se que o plano diretor é obrigatório para cidades:

I - com mais de vinte mil habitantes;

II - integrantes de regiões metropolitanas e aglomerações urbanas;

III - onde o Poder Público municipal pretenda utilizar os instrumentos previstos no $\S 4^{\circ}$ do art. 182 da Constituição Federal;

IV - integrantes de áreas de especial interesse turístico; (grifo nosso)

V - inseridas na área de influência de empreendimentos ou atividades com significativo impacto ambiental de âmbito regional ou nacional. (grifo nosso)

VI - incluídas no cadastro nacional de Municípios com áreas suscetíveis à ocorrência de deslizamentos de grande impacto, inundações bruscas ou processos geológicos ou hidrológicos correlatos. (Acrescentado pela L012.608-2012) (BRASIL, 2001).

Cabe aos profissionais comprometidos em desenvolver ações em prol do turismo e o lazer, e observar e ter ciência que essas atividades claramente acontecem no espaço e em territórios previamente instituídos (ora municipal, estadual ou federal); ocorre certamente ao Bacharel em Turismo a incumbência de olhar e participar da organização da cidade e do município também para o turismo, sob o enfoque da organização do espaço a partir das ferramentas legais existentes.

Trata-se de observar o espaço, perceber a cidade na sua essência, inter-relacionar o espaço vivido às formas de uso e ocupação do espaço.

O Plano Diretor deve estabelecer diretrizes para o esporte, lazer, moradia, comércio, entre outros equipamentos urbanos, públicos ou privados que necessitarão de planejamento para sua adequação e uso. Para essa organização espacial o zoneamento se faz necessário; é esse estudo e mapeamento que traça as diretrizes para a criação de um parque, de uma ciclovia, de um teatro, de um centro de eventos, estádios. Também cabe a essa norma regularizar a localização de construções como hotéis, pousadas, restaurantes. Enfim, por onde o turista caminha, circula e usufrui seus momentos de lazer acontecem a partir de sua vivência na cidade posterior ao que foi traçado e planejado às pessoas.

A relevância desse tema se dá em princípio, ao se observar cidades balneárias entulhadas de visitantes, sem abastecimento, sem espaço para usufruir caminhadas pela

1 Entende-se por município a porção geral do território que engloba a área rural e urbana, já a cidade é encarada nesse estudo como sede administrativa do município, geralmente a base urbanizada do município. 
orla, sem espaços nas rodoviárias ou aeroportos, sem espaços públicos de qualidade, com patrimônios históricos (potenciais recursos culturais) sendo destruídos ou engolidos pela pressão imobiliária. Entre outras realidades que se somam nessas cidades.

A intenção de incluir nos planos diretores municipais, capítulos específicos para a política de turismo, de incluir a discussão do turismo no zoneamento serve para fazer valer o que a Constituição e o Estatuto da Cidade definem como garantia de qualidade de vida de cidadãos. A inclusão do turismo nesses e em outros documentos e decisões da esfera legislativa e executiva dos municípios, influenciam diretamente nas políticas específicas de turismo, na composição da equipe técnica, na continuidade de trabalhos, planos e projetos, e no respaldo legal que os planos de turismo poderão ganhar, uma vez que o plano diretor após sua aprovação na esfera local possui um período de vigência (revisão a cada dez anos), independente de pleitos eleitorais.

O propósito de atrelar o Plano Diretor Municipal ao turismo se dá a partir de uma nova concepção de planejamento. Se as cidades organizam seus territórios para o comércio e para a indústria tradicionais, por que não buscar esforços à organização territorial do turismo? Claro que há uma dinâmica diversa àquelas já citadas, entretanto trata-se de buscar uma nova gestão às cidades, em que os planos possam prever o uso e a ocupação do solo para espaços públicos e privados que atendam a demanda de turismo, observadas a capacidade de recepção, numa visão de curto, médio e longo prazo.

\section{CONCLUSÕES}

A opinião da presente autora está atrelada a percepção de observar e conhecer leis brasileiras que possam contribuir ao planejamento do turismo, e por desconexão de metodologias de trabalho na esfera municipal que não estão subsidiando discussões e justificativas quanto a importância do planejamento do turismo adequado aos preceitos do desenvolvimento integrado.

Segue uma observação no sentido de que a investigação para o turismo, a partir do inventário turístico precisa ser espacializada para possibilitar uma visão geral dos 
equipamentos, atrativos, recursos naturais e culturais.

Essa atitude deve prever o desenvolvimento de atividades voltadas ao lazer e ao turismo numa visão global, em que o olhar do planejador possa desenvolver ações e promover investimentos na geração de produtos turísticos ordenados em espaços definidos numa previsão de capacidade de atração da demanda, em busca da consolidação da atividade sem ferir a capacidade de carga do destino ou provocar danos ao meio ambiente.

\section{REFERÊNCIAS}

BRASIL. Lei Federal $\mathbf{n}^{\mathbf{0}} \mathbf{1 0 . 2 5 7}$, de 10 de julho de 2001. Regulamenta os arts. 182 e 183 da Constituição Federal, estabelece diretrizes gerais da política urbana e dá outras providências. Índice Fundamental do Direito- DJi. Disponível em: <http://www.dji.com.br/leis_ordinarias/1-010257-10-07-2001.htm $>$. Acesso em: 20/12/2013.

KNAFOU, R. Turismo e Território: por uma abordagem científica do turismo. In: RODRIGUES, A. B. Turismo e geografia: reflexões teóricas e enfoques regionais. 3. ed. São Paulo: Hucitec, 2001. p. 62-74

YÁZIGI, E. Saudades do futuro: por uma teoria do planejamento territorial do turismo. São Paulo: Plêiade, 2009. 